\title{
THE EARLY DAYS OF SWATCH: BIRTH OF THE FAST FASHION WATCH BUSINESS MODEL
}

\section{ZAČECI SWATCHA: RAZVOJ POSLOVNOG MODELA BRZE MODE U INDUSTRIJI SATOVA}

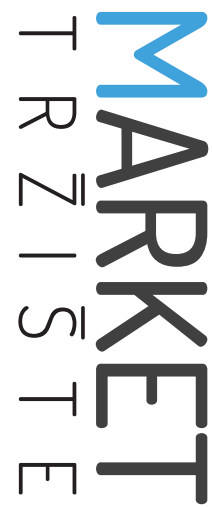

\author{
Market-Tržište \\ Vol. 30, №. 1, 2018, pp. 93-108 \\ UDK 391:658.624 \\ DOl http://dx.doi.org/10.22598/mt/2018.30.1.93 \\ Review
}

\author{
Nikola Draskovića , Milivoj Marković ${ }^{b}$, Christian Petersen ${ }^{c}$ \\ a) Rochester Institute of Technology Croatia, D. Tomljanovića Gavrana 15, 10000 Zagreb, CROATIA, nikola.draskovic@croatia. \\ rit.edu \\ b) Rochester Institute of Technology Croatia, D. Tomljanovića Gavrana 15, 10000 Zagreb, CROATIA, milivoj.markovic@croatia. \\ rit.edu \\ c) Insight Design Guide, B. Adžije 22/1, 10000 Zagreb, CROATIA, chris@insightdesignguide.com
}

\begin{abstract}
Purpose - The purpose of this study is to investigate the application of the fast fashion business model outside the apparel industry. The study reviews the business history of Swatch and investigates its business model at the time when the brand was introduced to the market. Swatch repositioned the watch as an accessory or a fashion item, rather than a timepiece, initiating a dramatic strategic shift within a rigid and traditional Swiss watch industry.

Design/Methodology/Approach - Due to the limited availability of studies researching applications of the fast fashion business model outside the apparel industry, this study is explorative in its nature and utilizes the case study method. The data necessary for developing a case study originates from secondary sources and from a series of in-depth interviews.
\end{abstract}

Findings and implications - Swatch developed a completely new business model to the watch industry. As the case analysis discusses, this model consisted of several elements commonly related to the fast fashion business model. This extended the fast fashion model across the traditional boundaries of the apparel industry.

Limitations - Due to a focus on one case study, which assumes industry specific factors, generalization of findings are limited.

\section{Sažetak}

Svrha - Svrha ovog rada jest istražiti primjenu poslovnog modela brze mode (fast fashion) izvan odjevne industrije. Ovaj rad analizira poslovnu povijest marke Swatch te istražuje njezin poslovni model u trenutku ulaska na tržište. Swatch je repozicionirao ručni sat kao modni dodatak, odnosno dio mode, nasuprot tradicionalnoj percepciji mjerača vremena. Taj je potez uzrokovao dramatičnu promjenu strategije unutar nefleksibilne i tradicionalne švicarske industrije satova.

Metodološki pristup - S obzirom na ograničenu dostupnost znanstvenih studija koje bi obrađivale aplikacije poslovnog modela brze mode izvan odjevne industrije, ova je studija eksplorativnog karaktera i primjenjuje metodu studije slučaja. Podaci potrebni za razvoj studije slučaja prikupljeni su iz sekundarnih izvora te kroz seriju dubinskih intervjua.

Rezultati i implikacije - Swatch je razvio potpuno nov poslovni model unutar industrije satova. Kao što analiza poslovne studije sugerira, riječ je o modelu koji se sastoji od nekoliko elemenata koji se vežu uz koncept brze mode (fast fashion). Ovo zapravo predstavlja slučaj korištenja modela brze mode u kontekstu izvan tradicionalnih granica modne industrije. 
Originality - Fast fashion related research is primarily focused on the apparel industry, as the environment in which the model was originally developed. This study extends fast fashion as a concept with valid applications outside its traditional industry.

Keywords - fast fashion, new product development, watch industry, business history, marketing strategy, country-of-origin effect
Ograničenja - S obzirom na usredotočenost na jednu studiju poslovnog slučaja koja uključuje faktore specifične za dotičnu industriju, ograničena je generalizacija rezultata istraživanja.

Doprinos - Istraživanje poslovnog modela brze mode primarno je usredotočeno na modnu industriju kao okruženje u kojem je navedeni model razvijen. Ovaj rad pristupa brzoj modi kao konceptu koji može funkcionirati i izvan svog tradicionalnog okruženja.

Ključne riječi - brza moda, razvoj novog proizvoda, industrija satova, povijest poslovanja, marketinška strategija, učinak zemlje podrijetla 


\section{INTRODUCTION}

As a contemporary term, fast fashion is mostly related to the clothing brands such Zara or $H \& M$. Sometimes referred to as a disposable or throwaway fashion concept, it is associated with delivering fashion products to a mass market at relatively low prices (Morgan \& Birtwistle, 2009; Hines, 2007). The watch industry follows different patterns. Traditionally, buying a high-quality handmade timepiece would probably occur just once or twice in a lifetime. However, even the very traditional and rigid wristwatch market changed with the automation of production in the 1950s and 1960s and the introduction of watches with quartz movement in the 1970s (Glasmeier, 2000). Technological advancements improved production efficiency and reduced cost, so the markets were flooded with cheaper and affordable watches. Thus, the buying patterns changed since even consumers with lower purchasing power could now afford a watch. The Swiss watch industry, as the long-standing world leader, did not embrace the technological change on time. Consequently, the industry was faced with a serious downturn and crisis in the late 1970s and early 1980s (Donzé, 2015). The salvation and rebirth of the Swiss watch industry is related to the introduction of Swatch - a plastic and inexpensive watch with quartz movement - together with the implementation of a new business model that repositioned the watch as an accessory or a fashion item, rather than a timepiece (Donzé, 2014).

The aim of this study is to review the business history of Swatch and the development and introduction of a new business model that strongly resembles the more recent concept of fast fashion. This study investigates the application of the fast fashion model outside the apparel industry by analyzing Swatch's turnaround strategy, introduced in the early 1980s, that drove the company toward the position of one of the largest wristwatch manufacturers in the world.

\section{BRIEF HISTORIC AND CONTEXTUAL BACKGROUND}

Besides banking and chocolate, watchmaking is among major Swiss industries with a tradition spanning more than four centuries (Fondation de la Haute Horlogerie, 2017). Initially developed by protestant Huguenots who found retreat in Geneva, Swiss watchmaking flourished during the $17^{\text {th }}$ and $18^{\text {th }}$ century (Donzé, 2015; Mudambi, 2005). For centuries, Swiss watchmakers dominated world markets. However, in the latter half of the $20^{\text {th }}$ century, some major product and production process improvements were introduced. As a major improvement, in the 1950s and the 1960s, mass production systems were developed and widely embraced by watchmakers worldwide (Glasmeier, 2000). However, the Swiss watchmaking industry just partially adopted these improvements, still focusing mostly on the cost intensive manual production of quality watches (Donzé, 2014).

Another blow for the Swiss watch industry came with the development and commercialization of quartz movement - a battery-powered, low cost and very precise alternative to the traditional mechanical movement. Surprisingly, the Swiss watch industry, led the process of research and development of the new technology together with Japan and the United States, but was unable to adopt and commercialize the innovation (Donzé, 2015). Japanese watch companies like Seiko, Citizen and Casio quickly switched to electronic watches and, as a result, Japan became a world leader in watch production by the late 1970s (Glasmeier, 2000).

As Japanese and Hong Kong producers flooded the lower-end market in the 1970s, they were not at first considered a real threat to established Swiss producers. The Swiss watch industry was, at some point, aware of the developing price competition. However, the industry was sure the "pin-lever", also called the roskopf watch (i.e. a thinner and lighter mechanical watch developed by G. F. Roskopf), would handle the Far

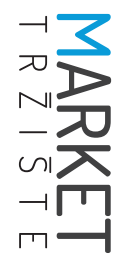


East competition (Dreifuss, 2011). The traditional Swiss watchmakers believed that only a mechanical movement would maintain their reputation and that quartz movement would betray the art of fitting 200-300 pieces into a mechanic watch movement. Unfortunately, that was just another self-deception. With time, as they established a stronger presence at the lower end of the market, Far Eastern producers started to trade up and gradually launch new watch models that took away even more market share from Swiss producers.

The emergence of quartz and the stillness of the Swiss watch industry prompted "the watchmaking crisis" between the mid-1970s and the mid-1980s, which put the industry's future and survival under serious threat (Donzé, 2015). The tide turned with the launch of Swatch in 1983 (Donzé, 2014). Soon after its introduction, the market accepted the new brand but also the concept of seasonal collections, frequent introductions of new designs and a very short product life cycle. Swatch was positioned as an accessory capable of measuring time. Due to its simple design, it was not possible to open the casing to repair the watch or to change a battery. It was a disposable watch with a limited life span, destined to be soon replaced by a newer trendy design. Consequently, a customer base of returning customers emerged, which was a completely new development within a very traditional watch market, especially among Swiss-made brands. Multiple purchases yielded higher revenues, which helped the industry to restructure and to re-establish itself on the world market (Donzé, 2011).

\section{LITERATURE REVIEW: STRATEGIC ASPECTS OF FAST FASHION}

The main idea underlining the fast fashion concept is to promote fashion consumption as something trendy, affordable, fast, and disposable (Payne, 2011). While the traditional fashion life cycle usually spans two yearly collections (seasons) with in-season replenishments, fast fashion moves away from this concept by introducing shorter product life cycles and creating smaller collections or merely a set of individual items (without replenishments) that are marketed more frequently as a quick response to fast-changing consumer demands (Barnes \& Lea-Greenwood, 2006). The fast fashion concept we recognize today emerged over many years as apparel retailers in general (and Zara and H\&M among apparel retailers in particular) were looking for a business model to provide a competitive advantage in the ever more dynamic apparel fashion industry (The Economist, 2005).

Industry dynamics fluctuate primarily for two main reasons: change in consumer tastes (reflected through demand pattern life cycles) and production and diffusion of knowledge or innovation (Grant, 2016). The fast fashion concept has been profoundly impacted by the confluence of both factors. By constantly striving to match and lead changing consumer tastes, fashion retailers started to introduce fresh designs of merchandise in shorter intervals of time, effectively shortening product life cycles (Collet, Cluver \& Chen, 2013).

This fashion trend was primarily picked up by young, fashion conscious consumers who were looking for trendy products at affordable prices, as the main value proposition of fast fashion. Such consumers are ideally fashion driven and seek immediate availability of currently trending items. The availability of different designs is very important for them, as is the low price and matching quality (Walters, 2006). Hines and Bruce (2001) point out specifically that fast fashion items primarily target female consumers within the 16 to 24 age group.

Delivering a product to the market faster than direct competition is not an instant source of success unless that product matches the specific and fast-changing needs and wants of fickle young consumers. Hence, the capabilities of fashion-oriented companies in recognizing those needs and designing and marketing appropriate garments emerged as a first step and 
key driver of success of the fast fashion business model.

Marketing efforts are not only directed at discovering the needs of consumers but on creating them as well. This is especially noticeable through the promotion of fashion products as (artificially) scarce, with limited time and quantity availability, and quickly disposable (Payne, 2011) which makes them inevitably "hot" and "fast". The resulting consumer excitement is reflected in long queues before store openings (La Ferla, 2000) and a high frequency of store visits. Many items (models) are almost never reproduced and resold and stock availability is minimum to none; the product is either bought on the spot or the real risk of not buying it ever is created. This approach results in less store-based inventory investment for the retailer as well as in less of a need for markdowns, clearance sales, and other in-store promotional efforts.

Throughout the 1970s and the 1980s companies increasingly realized that a faster delivery of goods to the market had numerous competitive benefits for them, especially in industries marked by fast-changing consumer tastes. Matching those trends and tastes faster (sooner) than competitors opens the possibility for higher lead margins, fewer clearance sales, lower warehousing costs, and higher-frequency visits of customers to the stores. Next to these firm level benefits, other benefits that span the entire supply chain are also achievable, most notably higher capacity utilization and shorter lead times through information exchange. The concept of Quick Response (QR) is used to denote these efforts (Harrison \& Hoek, 2008). QR is basically a set of technologies that enable higher levels of cooperation and coordination among supply chain participants (Palmer \& Markus, 2000). Other strategic concepts also emerged at the time, clearly showing a gradual increase in awareness of the new competitive advantage arising from fast time to market, such as timebased competition introduced by Stalk (1988).

Marketing demands for increasingly shorter lead times coupled with operational focus on low costs translate into a high need for coordination between adjacent phases of the supply chain (Choi, 2013; Sheridan, Moore \& Nobbs, 2006). The need for short lead times resulted in placing key supply chain functions in close proximity to main markets. Zara, for example, located its production facilities in close proximity to countries such as Spain, Portugal, Turkey, and Morocco in order to quickly serve the European market (Sowray, 2015; Escalona Orcao \& Ramos Pérez, 2014; Tokatli, 2008). As short lead times necessitated a high level of coordination, market-based relationships between adjacent phases of supply chain always had the risk of lurking opportunism which kept transaction costs relatively high. In order to keep them under control, Zara, for example, operates as a vertically integrated business model, with highly automated production processes (Petro, 2012) instead of outsourcing production to Far Eastern countries, as many other apparel retailers have done.

Smaller production batches spread out through multiple seasons throughout the year help increase the efficiency of the supply chain. Classic (two season a year) apparel retailers place their main orders twice a year, which causes severe strains across all the supply chain phases. Capacity is not utilized efficiently with high-low trend of sourcing and selling. On the other hand, multiple smaller if not continuous production runs throughout the year enable lower overall capacity installed and, consequently, its higher utilization (Caro \& Martínez-de-Albéniz, 2015). However, the need for coordination increases, which explains why many fast fashion companies opt for vertically integrated business model (Zara and Swatch, as will be demonstrated in subsequent analysis).

While the fast fashion business model is celebrated for its superior efficiency, its main critique is grounded in perceived lack of social responsibility of companies using the model. On the downstream part of the supply chain, the top of the concern list is occupied by the problem of environmental impact of disposed items once their quick and short life cycle ends (Nguyen,

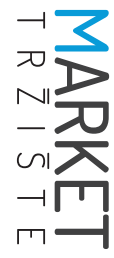




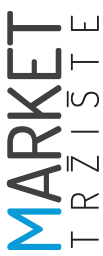

2012). On the upstream part of the supply chain, main concerns are related to lax work-related practices of fast fashion companies, which often locate production in low-income countries with an abundance of low-skill labor and weak regulatory framework (Arrigo, 2013).

The fast fashion model is not limited just to one specific formula. Due to a mix of various key success factors, companies developed their own customized business models to achieve strategic fit within their respective value chains. Their efforts have ranged from the retailing phase through upstream operations, which eventually resulted in a complete redesign of the entire supply chain of fashion products (Shen, 2014; Joy, Sherry, Venkatesh, Wang \& Chan, 2012; Lopez \& Fan, 2009; Tokatli, 2008). As Runfola and Guercini (2013) suggest, there is a variety of fast fashion formulas (FFF), such as:

- those focused on providing rapid proactive "services" to retail customers;

o those dedicated to the supply management and lead time reduction;

o those focused on eliminating the time lag between the design phase and introduction to the market;

o those aimed at reducing the time consumed during the creative/design process in order to push new products to the market in a timely manner.

In general, the fast fashion concept delineates an integrative business model, which spans the processes from creating and detecting consumer trends and engaging in closely coordinated production to the distribution of products in the shortest time possible. Product price must be as low as possible with commensurate quality and very trendy design. Lead time is of extreme importance to create the hype among consumers eagerly awaiting a new shipment and to decrease the possibility of fast competitor matching of design. Low production quantity which results in minimum or no stock aids retailers by eliminating the need for markdowns and acts as an incentive for the consumer to purchase on the spot without deferment. The long-term success factor for many fast fashion companies lies in replicating this pattern while maintaining the high appeal of its products.

While the fast fashion model is traditionally being investigated and analyzed within the boundaries of fashion industry, patterns of the model can be detected in other industries in which some companies also expedited their business models, e.g. Seven Eleven Japan (Matsuo \& Ogawa, 2007). Elements of the fast fashion model can also be detected within the consumer electronics industry, where the time between new product introductions is being reduced and more flexible production capacities are installed to respond to demand more quickly (Caro \& Martínez-de-Albéniz, 2015; Knowledge@Wharton, 2013).

\section{RESEARCH DESIGN}

\subsection{Research propositions}

The body of literature defines fast fashion as a concept that belongs to the fashion industry, and available studies commonly use different fashion companies as references. These limitations provoke interest for further research of the potential fast fashion model application in a complementary industry, such as fashion accessory industry. According to The Dictionary of Fashion History (Cumming, Cunnington \& Cunnington, 2010, p. 1), accessory is "an item which contributes to the overall effect but is of secondary importance [...] accessories usually complete an outfit and are chosen to complement it." Due to a vast number of fashion accessories, this study is limited to the watch industry.

With the introduction of Swatch, the Swiss watch industry embraced a new business strategy that clearly borrowed some ideas and concepts from the fashion industry and the fast fashion business model. Novelties, such as seasonal collections and trendy designs, innovated the industry and changed purchasing patterns among consumers. Therefore, the following research proposition is developed: 
P1. The business model introduced by Swatch is founded on elements of the fast fashion business model.

Having worked so well for many clothing companies, a natural development of the fast fashion model would be to test it in other industries as well. This is the new research direction that Caro and Martínez-de-Albéniz (2015) suggested in their concise review of the fast fashion business model. Having in mind the variety of FFFs (Runfola \& Guercini, 2013), the model's development outside the fashion industry must address other industry specifics. Therefore, the following research proposition is developed:

P2. The fast fashion model is applicable outside the fashion industry, but with necessary customization and adaptation.

\subsection{Research method}

Due to limited availability of research studies describing the application of the fast fashion model outside the fashion industry, this study has an explorative role. Thus, the inductive use of a qualitative case study has been selected as the most appropriate method. Case study itself could be defined as "an intensive study of a specific individual or specific context" (Trochim \& Donnelly, 2007, p. 147). Considering it a reference point in the context of industrial marketing (Piekkari, Plakoyiannaki \& Welch, 2009), Yin (2009, p. 18) provides a more comprehensive definition stating that the case study is "an empirical inquiry that investigates a contemporary phenomenon within its real-life context, especially when the boundaries between the phenomenon and context are not clearly evident." Due to its intensity, a case study requires data collection over a sustained period of time (Creswell, 2009). This empirical study is qualitative in its nature. The main advantage of the qualitative approach is that it "provides researcher with deeper levels of understanding new or complex phenomena by yielding a high level of detail" (Golic \& Davis, 2012, p. 732). The research method applied in this study follows the six-step process (i.e. plan, design, prepare, collect, analyze, and share), as suggested by Yin (2009).
Due to the uniqueness of the phenomenon (i.e. application of the FFF outside the fashion industry) and convenience, the case for this study was selected on the basis of purposive sampling (Yin, 2009; Patton, 2002). The data needed for the case study development was collected from publicly available secondary sources and through primary research. While secondary sources provided a general overview of the business history of Swatch, primary research yielded valuable insights into the developments behind the scenes. Furthermore, primary research also clarified some inconsistencies and missing links within secondary sources.

Primary research included two in-depth interviews with Mr. Peter Petersen, CEO of the Swatch SA between 1987 and 1998, conducted in 2015. As a member of the company's senior management, Mr. Petersen actively participated in the process of brand development and global market penetration in the early days of Swatch. The interviews were recorded and transcripts were developed for the purpose of qualitative analysis.

The interview agenda comprised general questions regarding the industry and historical context, together with more specific items addressing elements of the FFF revealed in the literature review. This approach combines exploration and theory testing research, in this particular order. As suggested by Dull and Hak (2008, p. 175), this approach represents "a more effective contribution to theory development than spending the same time and resources on theory-building research." The authors argue that interviewees (i.e. practitioners) are usually familiar with a range of basic theories or "theories-in-use" and that exploration is more appropriate for finding and formulating propositions than "discovering" new propositions.

\section{FINDINGS: THE SWATCH CASE STUDY}

After years of struggle with the Far Eastern and U.S. competition, the Swiss watch industry fu-

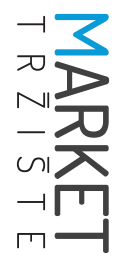


ture did not look bright at all in the 1970s. Obviously, there was a need for a dramatic change of strategy and business model. Instead of retreating toward the upper end of the market, the Swiss watch industry finally faced the cheaper Far Eastern competition by introducing Swatch. A combination of advanced engineering and innovative marketing approach, Swatch quickly became a global success and one of the most famous Swiss brands.

\subsection{The role of Nicolas G. Hayek in the emergence of Swatch}

From his early days, Nicolas G. Hayek was considered a very confident and unconventional thinker (Dreifuss, 2011). In 1979, a government-appointed group of Swiss banks hired Hayek's company to evaluate and report on how the two main Swiss watch manufacturers, ASUAG (Allgemeine Schweizerische Uhrenindustrie AG) and SSIH (Société Suisse pour I'Industrie Horlogère), could be most effectively sold (Pope, 2010). He investigated the industry and found that Swiss watchmakers were very inefficient due to a poor marketing strategy and lack of automation, resulting in declining sales and high production cost (Dreifuss, 2011). Hayek, coming from a different cultural background, had a much higher tolerance for risk, which differentiated him from his counterparts in the industry at the time. Instead of selling or shutting down the companies, he proposed a merger of ASUAG and SSIH, which took place in 1983 (Donzé, 2014). Due to his personal commitment and visionary thinking, banks largely followed Hayek's recommendation. However, despite obvious improvements and optimistic forecasts for the industry, the banks were not willing to continue with the project and wanted to sell their shares. This development turned into an opportunity for Hayek and he took a major stake in the newly formed group, now called Société Suisse de Microélectronique et d'Horlogerie (SMH), by buying a $51 \%$ share in 1984 (Childs, 2010). Hayek became the chairperson and CEO of SMH in 1986.

Hayek's restructuring plan for SMH had two major focuses. First, he recognized the potential of the high-end brands like Omega, Longines, Tissot, and Breguetbrand. He doubled their prices and emphasized the heritage value of the traditional Swiss industry (Childs, 2010). Furthermore, he had a clear vision for Omega to build a high-margin brand into a direct competitor for Rolex (Wegelin, 2010). On the other hand, Hayek also focused on the lower end of the market dominated by Far Eastern producers.

Although Hayek took a lot of credit for Swatch, the watch was actually developed by two engineers, Elmar Mock and Jacques Müller, under the supervision of Ernst Thomke (Childs, 2010). The first Swatch model was introduced in 1983, during Hayek's consulting era. Consequently, Hayek did not have the opportunity to actively participate in the process of new product development. However, Hayek's vision and innovative marketing approach made Swatch a very successful story by the late 1980s. From a marketing perspective, Swatch was positioned as a second watch and an accessory, rather than just a timepiece. The management considered it a key success to develop a customer base of repeat customers as it yielded sufficient revenue. In 1998, SMH changed its name to Swatch Group, additionally emphasizing the importance of the Swatch brand for the whole group.

\subsection{Product and process innovation}

The relatively low cost of production for Far Eastern watch manufacturers was one of the competitive elements that favored them when competing directly against Swiss-made watches. Traditional Swiss watches were technologically different. Their mechanical movement had a large number of parts that were assembled by skilled and well-trained employees, which also required a great deal of time. On the other hand, watches with quartz movement were much simpler with significantly higher precision in measuring time. The traditional manufacturing of Swiss-made watches took more working hours to manufacture, which meant a higher direct cost of labor (Donzé, 2015). 
In order to close the price gap between Swissmade watches and watches produced in countries with low labor costs, a complete change to the traditional Swiss concept of watch manufacturing model had to be introduced. The cost of direct labor had to be reduced significantly, together with the overall cost of production. During the research and development phase, Ernst Thomke set an initial production cost to be CHF 10 per unit, which would fall to CHF 5 per unit with economies of scale, resulting in $60 \%$ of the production cost at that time (Garel, 2015). Obviously, this required both product and production innovation.

Product innovation included design and manufacturing of a watch with quartz movement - a technology that the Swiss watch industry was not very enthusiastic about. To be able to compete in the same price category with Far Eastern and U.S. competitors to a degree, plastic materials had to be used instead of traditional metal ones, the movement was to be electronic with an analogue display and - as a particular novelty - once made, the casing of the watch could not be opened. This meant that any repairs to the watch were practically impossible.

Engineers under Ernst Thomke's supervision designed a watch that contained only 51 parts, down from between 90 to 150 for a conventional analogue quartz watch (Tushman \& Radov, 2000). Furthermore, the engineers developed a method of mounting movements and other parts directly into the watch casing, as opposed to the traditional building of a casing around the watch after the movement was assembled (Tushman \& Radov, 2000). This innovation also saved time in the production process and increased overall efficiency.

In order to produce such a timepiece, Swatch built production facilities from the bottom up and in doing so drew on the rich expertise of Swiss engineers. The traditional proficiency paired with innovation in the manufacturing of plastic parts (injection molding) for the quartz movement were the crucial components to its success. The highly automated production pro- cess provided two important opportunities for Swatch. First, the automated production process provided the opportunity for large-scale production and, second, the unit cost of the Swatch enabled the company to place the offering within the same product category as its main competition.

Additionally, with the integrated production process and manufacturing facilities under full control and ownership, Swatch was able to provide a quick response to any type of change in product design (Hines, 2007). This effectively shortened cycle time for Swatch products and provided Swatch with technical capabilities to introduce more varieties of watch designs within the same period of time necessary for competitors to be able to do the same. While traditional watch producers spent years developing new models, Swatch established a six-month lead time between design phase and collection launch. Technically speaking, every six months Swatch's internal design departments (i.e. Swatch Design Lab) in Milan, Tokyo, and New York would prepare an extensive portfolio of designs for the next collection. In the late 1980s, designers would come up with more than 400 designs in this proposal phase. After initial internal screening, around 150 designs would circulate between the three design departments for further assessment. With multicultural design teams working from three separate locations on assessing each other's proposals, only the designs that would fit the global taste would be selected. However, regional versions of the collections were developed sometimes.

\subsection{Marketing approach behind Swatch turnaround}

Beyond the technical aspects of product and process innovation, the key distinction of the business model that separated Swatch from other Swiss watch producers was their marketing approach (Morrison \& Bouquet, 1999). Swatch had a significantly different approach to marketing than other Swiss watch manufacturers had ever had. Manufacturing flexibility provided by the production processes was fully

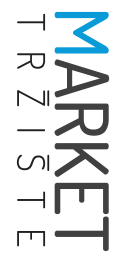


exploited in the overall shift of Swatch from a production-based business model, traditionally present in the Swiss watch industry, toward a market-led business model.

Hayek realized that the label "Swiss Made" was a strategic asset. He reasoned that timepieces that were direct competitors and sold at similar price points would be differentiated, among other things, based on their country-of-origin (Taylor, 1993). Without doubt, the "Swiss Made" label drove sales of Swatch:

We have realized that "Made in Switzerland" is a driving factor for watches. [...] Consumers were willing to pay a premium price for a plastic Swiss watch. (P. Petersen)

However, this could also hinder attempts to lower cost due to higher labor cost in Switzerland and the so-called "Swiss-made" legislation that limited the use of imported parts for watch movements up to $50 \%$ of the value of the parts as a whole (Donzé, 2014). Therefore, Swatch did not have an option to move production to the countries with lower labor cost, as many of global companies did to reduce production cost. Swatch had to focus on improving efficiency within its production plants in Switzerland, mainly by reducing the impact of labor. By fully automating the production process and designing-for-manufacture, Swatch was able to decrease direct labor cost to below $10 \%$ of a watch's retail price. Furthermore, by commanding a country-of-origin price premium of roughly the same amount, the low-cost advantage of Far Eastern producers was effectively eliminated from the competitive equation (Taylor, 1993).

Since both the Swiss watch industry and the Swiss market were traditional and conservative at that time, the new watch was first introduced to the U.S. market in late 1982. A limited quantity of 10,000 watches was put on sale in Houston, Texas (Garel, 2015). Although this was a commercial failure, it provided a valuable lesson. The design had to be changed because the first Swatch models did not differ significantly from the traditional mechanical watches, and the marketing effort had to be more intense (Donzé, 2014). Consequently, Marvin Traub, CEO of Bloomingdale's, requested two collections per year with at least twenty different models, in both colorful and designer watches (Garel, 2015).

The second launch occurred on March 1st, 1983 in Zurich, when Swatch launched the redesigned 12-model collection at prices ranging from CHF 39.90 to 50. Thanks to a successful launch, all the prices were raised to CHF 50 by the end of 1983 (Mudambi, 2005). In the 1970s and early 1980s, it seemed almost impossible to produce a watch in Switzerland and sell it for CHF 50 because the cost to produce even the cheapest watch in 1980 was CHF 25 (Garel, 2015). However, Swatch made it, while achieving very good margins. Swatch essentially rebuilt the entire value chain to create a strategic fit with the new competitive environment, while simultaneously benefiting from the perceptions of quality that consumers traditionally attached to Swiss-made watches. Redesign of the entire value chain had the most profound impact on the marketing approach of Swatch (Bruce \& Daly, 2006). By achieving price parity against its main competitors within the key product categories and having the operational capabilities to respond quickly to changing consumer tastes, Swatch created prerequisites for a deployment of a unique marketing strategy within the Swiss watch industry.

Since Swatch watches were not capable of being repaired, which was not only a novelty for the Swiss-made watch but for the watch market in general, the price point had to be low enough not to discourage buyers from purchasing but also to provide an adequate margin for Swatch. Quality uncertainty was to a degree addressed by the Swiss-made label, and relatively low pricing was possible due to low production costs. For Swatch to be able to achieve adequate revenues and growth, it was apparent that it needed to sell large quantities of watches. The Swatch management team concluded that large targeted unit sales were only achievable by stepping away from a traditional marketing 
approach. The big idea was to create a watch that functions as a fashion product rather than a pure timepiece:

The designs were very unconventional. Watches were not unicolor. They were covered with different patterns and it was not always easy to read the time. (P. Petersen)

When the purchasing decision becomes an emotional rather than a rational one, large quantities can be reached. Swatch watches effectively became disposable fashion. A type of watch you would wear for a while and then dispose of without high value loss. Relatively affordable prices also allowed target consumers to own multiple Swatch watches that would suit their different needs and occasions.

During the early years, distributors did not accept the idea of a disposable watch warmly. Traditional distributors of Swiss-made watches were jewelers who also collected a significant portion of revenues from watch repair. With the Swatch design and manufacturing process, watch repair was not an option; hence, an opportunity for revenues beyond selling was eliminated. Consequently, at the beginning, jewelers refused to carry the Swatch as the cheap plastic quartz watch simply did not fit their traditional inventory. Hence, Swatch was, to a degree, forced to use nonconventional retail outlets for selling watches, such as department stores and even on board of airplanes:

One of our first distribution channels were airlines, in flight sales. [...] People were calling the flight-booking department to check if they are going to have a certain model of Swatch for sale on board. (P. Petersen)

In 1988, the management decided that department stores were not an emotional environment for the sale of the product, leading to the idea of a self-developed distribution channel. This idea was not well-received among business analysts because the creation of a completely new retail outlet with only one product was considered highly questionable to say the least. Nevertheless, Swatch management introduced flagship stores (i.e. an outlet carrying a single brand), a common concept within the fashion industry where the consumer could feel the brand (Kapferer \& Bastien, 2012). Besides providing customers with an emotional retail environment designed to convey the brand's message, Swatch provided a certain level of exclusivity for its products.

It became obvious that Swatch's target audience would not include older generations as their concept of buying a timepiece (i.e. a big decision made once or twice in a lifetime) was in opposition with the watch concept that Swatch needed to offer. Swatch had to focus on creating an appeal to the younger audience as the primary target market. Therefore, the Swatch timepiece needed to be a fashionable product and Swatch Lab designers managed to provide a fashionable design (Taylor, 1993). To create strong consumer interest, design was changed frequently, a feature made possible by short time to market. This approach led to an increased number of product lines (seasons) compared to other watch manufacturers. Swatch introduced two seasonal collections per year, which could be considered another strategic drift from the traditional watch industry that would keep the same models for years. Moreover, Swatch introduced limited edition specials in between its standard collections, thus further shortening time to market and maintaining the hype for its products throughout the year. This approach helped create excitement among target customers in anticipating new watch designs to reach the market. Additional excitement was accentuated by the fact that the same watch design was never repeated, which resulted in long queues in front of their flagship stores when a new collection was launched.

Advertising efforts greatly supported the Swatch marketing and production model. Constant and aggressive marketing with innovative product placings exposed the Swatch brand to its target market with high intensity. Swatch launched highly publicized campaigns such as when, in 1984, a functioning 13-ton watch was mounted

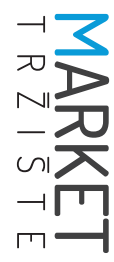




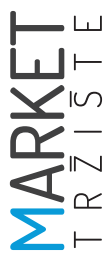

on the headquarters of Commerzbank in Frankfurt, Germany. The same approach was used in Tokyo with commensurate success (Taylor, 1993). Swatch's production model, paired with an innovative marketing strategy, suggests that technical innovation is not sufficient to create a successful brand but that it has to be linked to market demands and be marketed when the occasion arises (Proctor, 1998). Meanwhile, traditional sales arguments were reliability and price, particularly with Asian Far Eastern quartz watches. Swatch changed that and considered price and quality a given, therefore focusing on marketing Swatch as a lifestyle product. This can be further observed in Swatch's effort with regard to sports marketing. Swatch was a trailblazer in this arena, sponsoring any unique sport, from snowboarding to beach volleyball, and thus enforcing the brand's idea of an individual and exiting lifestyle.

\section{DISCUSSION}

As the case study revealed, at the time of its emergence, the Swatch business model was radically different from anything that existed in the Swiss watchmaking industry. The traditional Swiss-made watch received a cheaper, plastic, and trendy incarnation, positioned as a fashion piece rather than a timepiece. Although Swatch sold at CHF 50 was not inexpensive compared with the Far Eastern competition, it was very cheap for a Swiss-made watch and, therefore, quite affordable. Swatch introduced two seasonal collections per year, a concept borrowed from the traditional apparel industry (Springsteel, 2013). With frequent seasonal collections, consisting of unique designs that were not repeated in later collections, Swatch motivated consumers for multiple purchases a year, resulting in disposable products. This is another of the main characteristics of fast fashion (Watson \& Yan, 2013; Payne, 2011). Swatch also followed fashion trends and adapted its design to appeal to trendy consumers, another strategy not followed by the traditional watch manufacturers, but common for fast fashion brands (Collet et al., 2013; Morgan \& Birtwistle, 2009; Hines, 2007). Furthermore, Swatch vertically integrated the production process to support a relatively fast cycle of collections and six months lead time for a new collection, resulting in a very short product lifecycle within the watch industry. This way, Swatch was able to quickly introduce new designs to the market, which is the crux of fast fashion (Hines, 2007). Obviously, Swatch successfully adopted multiple concepts from the fast fashion business model, which provides support for P1.

Although fast fashion could be considered a unique model, there is a spectrum of FFFs adopted within the fashion industry itself (Runfola \& Guercini, 2013). Due to specific markets, consumer preferences, and internal capabilities, companies tend to develop their own variants of the fast fashion model. Taking into account the specifics of the watch industry, Swatch customized few elements of its FFF. For example, lead time for a new collection is longer then in the case of fashion industry. Furthermore, Swatch reinvented the industry with the introduction of two seasonal collections. Within the watch industry, that would traditionally keep the same models for years, this innovative move resulted in extremely short lifecycles compared with industry standards.

Besides the common elements found in the fast fashion model, swatch emphasized an additional factor within its FFF. As a side effect of the vertical integration and short lead time, Swatch relies on the country-of-origin effect. While the country-of-origin effect refers to stereotyping and generalization of the quality of products originating from an individual country (Suh, Hur \& Davies, 2016), the effect itself differs among different product categories and countries (Costa, Carneiro \& Goldszmidt, 2016). However, Swiss-made has a certain value for consumers within the context of the watch industry (Breiding, 2013; Taylor, 1993). While the country-of-origin effect is not commonly considered as an element of the fast fashion business model, it proved to be one of the key success factors 
for Swatch and a unique element of its FFF. The case study clearly demonstrated the applicability of the fast fashion model within the watch industry. However, successful application also requires customization and adaptation of the model, which is also detected in the case of Swatch. Therefore, research findings provided support for P2.

Figure 1 highlights the key strategic components within Swatch's business model introduced in 1980s as indicated by this study. It is evident that most of these elements, successfully developed and applied by Swatch, are indistinguishable from the characteristics commonly attributed to the FFF.

FIGURE 1: Elements of Swatch's fast fashion formula

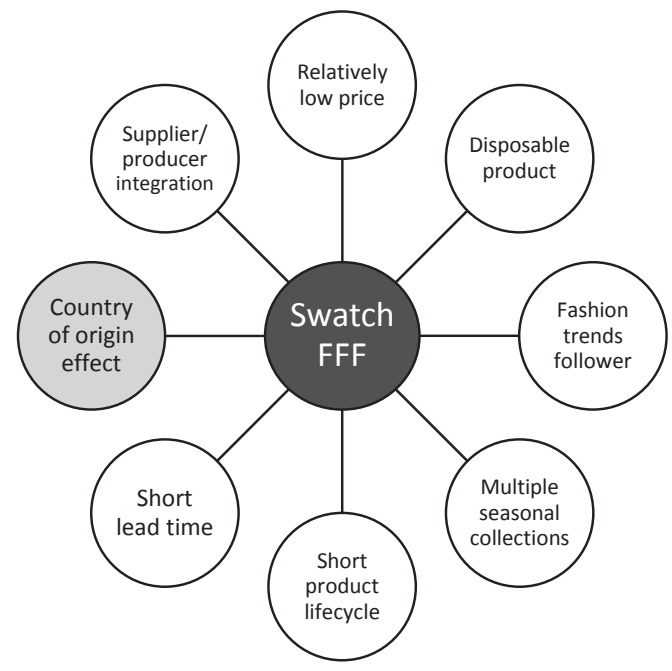

Source: authors' own work

\section{CONCLUSION}

Faced with the threat of extinction, Swatch emerged as a brand that innovated and established a strong market presence by moving away from the traditional Swiss watch-making business model. Swatch implemented aspects of the fast fashion business model to its turnaround strategy. The new strategy was a result of joint efforts of Ernst Thomke and Nicolas G. Hayek. While Thomke was focused on the technological aspects of the new watch, Hayek, a creative and unconventional thinker, was the strategic and marketing mastermind of Swatch. Hayek introduced a business model and marketing strategy that represented novelty within the rigid and traditional Swiss watch industry. The new marketing strategy essentially changed the way consumers perceived the product category. Instead of just being a timepiece, a watch became an accessory, a fashion icon with a short lifecycle. In essence, Hayek provided consumers with affordable and disposable watches with the all the positive effects that came with the "Swiss Made" label.

Carried out within the context of the Swiss watch industry, this study is limited in scope. Furthermore, our analysis has focused on a single case study, which probably additionally limits its external validity. However, its in-depth analysis of the particular phenomenon yielded valuable insights into the application of the FFF outside the apparel industry. As the case analysis suggests, innovation and fresh perspective leading to a major strategic shift could save an industry from its extinction.

This study provides empirical support for the application of the fast fashion model outside the apparel industry, which is a topic that has received very limited attention among researchers. Since the study managed to establish a firm link between the application of the fast fashion business model and the success of Swatch, the findings may encourage other researchers to explore full or partial applications of the model outside the apparel industry. Furthermore, the case of Swatch may also provide a reference and an inspiration to marketing managers trying to reinvent more or less traditional markets and products. However, the fact that each industry has some specifics and lead times could be perceived differently should also be considered. As this study reveals, Swatch's FFF is not as "fast" as is the case with fast fashion apparel brands, such as Zara or H\&M, with the lead time cut

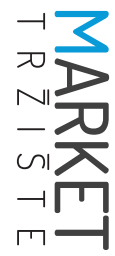


down to a few weeks. Nevertheless, compared with watch industry standards, Swatch's business model introduced very short lead times and product lifecycles. Thus, "fast" seems to be a relative and industry specific variable within a business model outside the apparel industry.
Although Swatch is still considered as a successful brand, new challenges are arising. With the market introduction of the so-called "smartwatch" concept (e.g. Apple Watch and Samsung Gear), the concept of a wristwatch is again being redefined. Until now, there were no indications that Swatch was going to enter this new product category.

\section{References}

1. Arrigo, E. (2013). Corporate responsibility management in fast fashion companies: the Gap Inc. case. Journal of Fashion Marketing and Management: An International Journal, 17(2), 175-189.

2. Barnes, L., \& Lea-Greenwood, G. (2006). Fast fashioning the supply chain: shaping the research agenda. Journal of Fashion Marketing and Management: An International Journal, 10(3), 259-271.

3. Breiding, R. J. (2013). Swiss made: the untold story behind Switzerland's success. London: Profile Books.

4. Bruce, M., \& Daly, L. (2006). Buyer behaviour for fast fashion. Journal of Fashion Marketing and Management, 10(3), 329-344.

5. Caro, F., \& Martínez-de-Albéniz, V. (2015). Fast Fashion: Business Model Overview and Research Opportunities. In: N. Agrawal \& S. A. Smith (Eds.). Retail Supply Chain Management: Quantitative Models and Empirical Studies (pp. 237-264). New York, NY: Springer.

6. Childs, M. (2010). Nicolas Hayek: Entrepreneur who created the Swatch brand and saved the Swiss watchmaking industry. Independent. Available at: http://www.independent.co.uk/news/ obituaries/nicolas-hayek-entrepreneur-who-created-the-swatch-brand-and-saved-the-swisswatchmaking-industry-2021119.html (accessed on March 22 ${ }^{\text {nd }}, 2016$ ).

7. Choi, T-M. (2013). Local sourcing and fashion quick response system: the impacts of carbon footprint tax. Transportation Research, Part E, 55(1), 43-54.

8. Collet, M., Cluver, B., \& Chen, H-L. (2013). Consumer Perceptions the Limited Lifespan of Fast Fashion Apparel. Research Journal of Textile and Apparel, 17(2), 61-68.

9. Costa, C., Carneiro, J., \& Goldszmidt, R. (2016). A contingent approach to country-of-origin effects on foreign products evaluation: Interaction of facets of country image with product classes. International Business Review, 25(5), 1066-1075.

10. Creswell, J. (2009). Research Design; Qualitative and Quantitative and Mixed Methods Approaches. London: Sage.

11. Cumming, V., Cunnington, C. W., \& Cunnington, P. E. (2010). The Dictionary of Fashion History. Oxford: Berg Publishers.

12. Donzé, P-Y. (2011). The comeback of the Swiss watch industry on the world market: a business history of the Swatch Group (1983-2010). MPRA Paper No. 30736. Available at: https://mpra.ub.unimuenchen.de/30736/ (accessed on September 20 th, 2017).

13. Donzé, P-Y. (2014). A Business History of the Swatch Group: The Rebirth of Swiss Watchmaking and the Globalization of the Luxury Industry. Hampshire: Palgrave Macmillan.

14. Donzé, P-Y. (2015). History of the Swiss Watch Industry: From Jacques David to Nicolas Hayek (3 ${ }^{\text {rd }}$ ed.). Bern: Peter Lang.

15. Dreifuss, M. (2011). Swiss Watch Industry. Available at: http://forums.watchuseek.com/ f66/\%93without-senior-hayek-there-would-not-swiss-watch-industry-anymore-\%94-567890. html (accessed on February 28 ${ }^{\text {th }}, 2016$ ). 
16. Dull, J. \& Hak, T. (2008). Case study methodology in business research. Oxford: Taylor \& Francis.

17. Escalona Orcao, A., I. \& Ramos Pérez, D. (2014). Global production chains in the fast fashion sector, transports and logistics: the case of the Spanish retailer Inditex. Investigaciones Geográficas, Boletín del Instituto de Geografía, 85, 113-127.

18. Fondation de la Haute Horlogerie (2017). History. Available at: https://www.hautehorlogerie.org/ en/encyclopaedia/history-of-watchmaking/ (accessed on March 20 ${ }^{\text {th }}, 2017$ ).

19. Garel, G. (2015). Lessons in Creativity from the Innovative Design of the Swatch. Technology Innovation Management Review, 5(7), 34-40.

20. Glasmeier, A. K. (2000). Manufacturing Time: Global Competition in the Watch Industry, 1975-2000. New York, NY: The Guilford Press.

21. Golic, S. L., \& Davis, D. L. (2012). Implementing mixed method research in supply chain management. International Journal of Physical Distribution \& Logistics Management, 42(8), 726-742.

22. Grant, R. M. (2016). Contemporary strategy analysis. $8^{\text {th }}$ ed. Chichester: John Wiley \& Sons.

23. Harrison, A., \& Hoek, V. R. (2008). Logistics management and strategy competing through the supply chain. Harlow: FT Prentice Hall.

24. Hines, T., \& Bruce, M. (2001). Fashion Marketing: Contemporary lssues. Oxford: Butterworth-Hinemann.

25. Hines, T. (2007). Globalization: Global markets and global supplies. In: T. Hines \& M. Bruce (Eds.). Fashion Marketing Contemporary Issues (pp. 1-26). Oxford: Elsevier.

26. Joy, A., Sherry, J. F., Venkatesh, A., Wang, J., \& Chan, R. (2012). Fast Fashion, Sustainability, and the Ethical Appeal of Luxury Brands. Fashion Theory, 16(3), 273-295.

27. Kapferer, J-N., \& Bastien, V. (2012). The Luxury Strategy: Break the Rules of Marketing to Build Luxury Brands ( $2^{\text {nd }}$ ed.). London: Kogan Page.

28. Knowledge@Wharton (2013). Still Hot - or Not? Technology Firms Face Faster Product Cycles. University of Pennsylvania. Available at: http://knowledge.wharton.upenn.edu/article/still-hotor-not-technology-firms-face-faster-product-cycles/ (accessed on September 14 ${ }^{\text {th }}, 2017$ ).

29. La Ferla, R. (2000). 'Cheap Chic' Draws Crowds on $5^{\text {th }}$ Ave. The New York Times. Available at: http:// www.nytimes.com/2000/04/11/style/cheap-chic-draws-crowds-on-5th-ave.html?pagewanted=all (accessed on March 14 $4^{\text {th }}, 2017$ ).

30. Lopez, C., \& Fan, Y. (2009). Internationalisation of the Spanish fashion brand Zara. Journal of Fashion Marketing and Management: An International Journal, 13(2), 279-296.

31. Matsuo, H., \& Ogawa, S. (2007). Innovating innovation: The case of Seven-Eleven Japan. International Commerce Review, 7(2), 104-114.

32. Morgan, L. R., \& Birtwistle, G. (2009). An investigation of young fashion consumers' disposal habits. International Journal of Consumer Studies, 33(2), 190-198.

33. Morrison, A., \& Bouquet, C. (1999). Swatch and the Global Watch Industry, business case. London: Richard Ivey School of Business.

34. Mudambi, R. (2005). Branding Time: Swatch and Global Brand Management. Temple University IGMS Case Series No. 05-001. Philadelphia, PA: Temple University.

35. Nguyen, M. (2012). Overdressed: The shockingly high cost of cheap fashion. Toronto: Rogers Publishing.

36. Palmer, J. W., \& Markus, M. L. (2000). The performance impacts of quick response and strategic alignment in specialty retailing. Information Systems Research, 11(3), 241-259.

37. Patton, M. Q. (2002). Qualitative Research and Evaluation Methods. $3^{\text {rd }}$ ed. Thousand Oaks, CA: Sage.

38. Payne, A. (2011). The life-cycle of the fashion garment and the role of Australian mass market designers. The International Journal of Environmental, Cultural, Economic and Social Sustainability, 7(3), 237-246. 
39. Petro, G. (2012). The Future Of Fashion Retailing: The Zara Approach. Forbes. Available at: http:// www.forbes.com/sites/gregpetro/2012/10/25/the-future-of-fashion-retailing-the-zara-approach-part-2-of-3/\#5ac2ff4d39a0 (accessed on March 15 ${ }^{\text {th }}, 2017$ ).

40. Piekkari, R., Plakoyiannaki, E., \& Welch, C. (2009). 'Good' case research in industrial marketing: Insights from research practice. Industrial Marketing Management, 39(1), 109-117.

41. Pope, S. (2010). Swatch Billionaire Nicolas Hayek, Who Saved The Swiss Watch Industry, Dies. Forbes. Available at: http://www.forbes.com/sites/billions/2010/06/29/swatch-billionaire-nicolas-hayekwho-saved-the-swiss-watch-industry-dies/\#39a64d6e4427 (accessed on March 20 ${ }^{\text {th }}, 2017$ ).

42. Proctor, T. (1998). Innovations in time: What can we learn from history?. Creativity and Innovation Management, 7(4), 204-211.

43. Runfola, A., \& Guercini, S. (2013). Fast fashion companies coping with internationalization: driving the change or changing the model?. Journal of Fashion Marketing and Management: An International Journal, 17(2), 190-205.

44. Shen, B. (2014). Sustainable Fashion Supply Chain: Lessons from H\&M. Sustainability, 6(9), 62366249.

45. Sheridan, M., Moore, C., \& Nobbs, K. (2006). Fast fashion requires fast marketing: The role of category management in fast fashion positioning. Journal of Fashion Marketing and Management: An International Journal, 10(3), 301-315.

46. Sowray, B. (2015). The 5 ingredients of Zara's success. The Telegraph. Available at: http://www. telegraph.co.uk/fashion/brands/the-5-ingredients-of-zaras-success/ (accessed on March 20 ${ }^{\text {th }}$, 2017).

47. Springsteel, L. J. (2013). Becoming a Fashion Designer. Hoboken: John Wiley \& Sons.

48. Stalk, G. Jr. (1988). Time - the next source of competitive advantage. Harvard Business Review, 66(4), 41-51.

49. Suh, Y., Hur, J. Y., \& Davies, G. (2016). Cultural appropriation and the country of origin effect. Journal of Business Research, 69(8), 2721-2730.

50. Taylor, W. (1993). Message and muscle: An interview with Swatch titan Nicolas Hayek. Harvard Business Review, 71(2), 98-110.

51. The Economist (2005). The future of fast fashion. The Economist. Available at: http://www.economist.com/node/4086117 (accessed on March 20 ${ }^{\text {th }}, 2017$ ).

52. Tokatli, N. (2008). Global Sourcing Insights from the Clothing Industry: The Case of Zara, a Fast Fashion Retailer. Journal of Economic Geography, 8(1), 21-38.

53. Trochim, W. M. K., \& Donnelly, J. P. (2007). Research Methods Knowledge Base. Mason: Thomson.

54. Tushman, M. L., \& Radov, D. B. (2000). Rebirth of the Swiss Watch Industry: 1980-92 (case study). Boston, MA: Harvard Business School.

55. Walters, D. (2006). Demand chain effectiveness - supply chain efficiencies: A role for enterprise information management. Journal of Enterprise Information Management, 19(3), 246-261.

56. Watson, M. Z., \& Yan, R.-N. (2013). An exploratory study of the decision processes of fast versus slow fashion consumers. Journal of Fashion Marketing and Management: An International Journal, 17(2), 141-159.

57. Wegelin, J. (2010). Mister Swatch: Nicolas Hayek and the Secret of his Success. London: Free Association Books.

58. Yin, R. K. (2009). Case Study Research: Design and Methods (4 $4^{\text {th }}$ ed.). Thousand Oaks, CA: Sage Publications. 